\title{
Word-finding whimsy
}

Christina Shenvi, MD, PhD

Neurolog $y^{\circledR}$ 2018;91:568-569. doi:10.1212/01.wnl.0000544323.09014.c0

I'm feeling much older with every day.

More tired, more muddled, life wisping away.

And lately I've noticed I've been having more trouble,

Remembering words like "hairbrush" or "bubble."

Words seem immeasurably harder to find.

Right when I need them, they've slipped my mind!

There's one right now I've been rooting out,

But it keeps on jumping and slipping about.

The harder I try, the faster it moves.

Now it's hiding in one of my postcentral grooves.

Could I have left it in the wrong frontal gyrus?

Did it slip down a sulcus and into a sinus?

I felt it move now! It dropped onto my brainstem.

It wriggled along, down towards the foramen

To my facial nerve, where it's started to burrow,

Which makes my lips purse, and my eyebrows furrow.

That mischievous word, I can feel it gloat;

It's lodged in my neck as a lump in my throat,

Now it followed the sympathetics up to my eyes.

It's making me tear. Please don't start to cry?

People around me say I look confused.

"Turn your hearing aid up," they say, amused.

They don't understand that I hear them just fine.

The problem is just that I'm losing my mind.

I hope you can sense all my utter frustration;

My doc is no help, with his prognostication.

I'm tired of his long-winded, hand-waving know-how.

Just give me a pill, something quick, something now.

\section{Correspondence}

Dr. Shenvi

cshenvi@med.unc.edu

\section{MORE ONLINE}

\section{ค Audio}

Listen to Dr. Shenvi read this poem.

NPub.org/d7brhk

He says that no pills can cure what ails me,

My own old age is the foe that assails me.

My neurons don't fire with speed and precision.

My dendrites get tangled with every decision. 
People wait with thin patience as I look for the word, Speak slowly and loudly, as if I've not heard.

It's no use. I can't find it. It's no good contending.

I may as well forfeit this game of remembering.

I play this small game so that I won't despair, When I look for a word and the word isn't there.

It must be important to be hiding this way. But wait! There it is, my word of the day! It's "mattress," I'm sure of it. Hip hip hooray! Now why did I need it?

I just can’t say. 


\title{
Neurology
}

\author{
Word-finding whimsy \\ Christina Shenvi \\ Neurology 2018;91;568-569 \\ DOI 10.1212/01.wnl.0000544323.09014.c0
}

This information is current as of September 17, 2018

\section{Updated Information \& Services}

Subspecialty Collections

Permissions \& Licensing

Reprints including high resolution figures, can be found at: http://n.neurology.org/content/91/12/568.full

This article, along with others on similar topics, appears in the following collection(s):

\section{Dementia aphasia}

http://n.neurology.org/cgi/collection/dementia_aphasia

Information about reproducing this article in parts (figures,tables) or in its entirety can be found online at:

http://www.neurology.org/about/about_the_journal\#permissions

Information about ordering reprints can be found online:

http://n.neurology.org/subscribers/advertise

Neurology ${ }^{\circledR}$ is the official journal of the American Academy of Neurology. Published continuously since 1951, it is now a weekly with 48 issues per year. Copyright () 2018 American Academy of Neurology. All rights reserved. Print ISSN: 0028-3878. Online ISSN: 1526-632X.

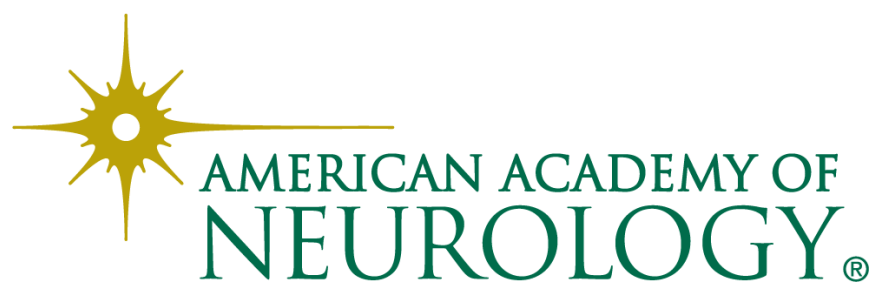

